\title{
THE HUMANISTIC APPROACH IN PHYSIOTHERAPY $\dagger$
}

\author{
The Role of the Physiotherapist in Motivating and \\ Counselling the Patient
}

N. LENNARD, B.Sc. Physio. (Rand)*

\begin{abstract}
Die skryfster beklemtoon die belang van motivering Die skrying as deel van die rol wat die fisioterapeut ch in ' $n$ noue en dikwels intieme verwantskap met 'n het in 'n wat gerehabiliteer word. Hierdie verwantskap pasient wat uit die fisieke kontak gedurende behandeling. vlcei voort beter voorbereiding vir en insig in hierdie So bepleit beter voorbereiding vir en insig in hierde viters belangrike aspilitasie hang grotendeels af van 'n dan nie, van rehabilitasie uitvoering van hierdie belangrike taak.
\end{abstract}

The following definitions were published by the Chartered Society of Physiotherapy in its Journal in April 1975, in an article written by Doreen Bauer.

"Physiotherapy is the art and science of therapeutic movement supplemented by the selective application of certain physical agents which may relieve pain and enhance tissue response and programmed upon the evaluation of a detailed assessment based upon a physician's diagnosis and relevant medical information."

A physiotherapist is a skilled person who should on consultation with a physician be capable of applying his or her own judgement and knowledge and training for the appropriate assessment and treatment of a patient.

The role of a physiotherapist embraces nine equal functions: (1) Assessing. (2) Evaluating. (3) Programme planning. (4) Teaching, instructing and training. (5) Motivating or counselling. (6) Treating. (7) Supervising. (8) Recommending. (9) Documenting.

It is Number 5 on the list, Motivating and Counselling which I propose to discuss. Although motivating and counselling the patient is an inherent part of the practice of physiotherapy, the physiotherapist may recognise her role in motivating the patient but not be fully aware of her power and influence as an indirect counsellor of the patient. She may feel that she does not have sufficient training or she may lack confidence in her ability to counsel, yet her contact with the patient is often so close that she is the best person available to do so. In fact the patient will solicit her opinion or the circumstances will be such that adequate replies or advice must be given before the patient will be satisfied.

Where the patient is concerned it is always the physical aspect which is the official reason for consulting the physiotherapist. The physical element is often the least important, yet in the eyes of the patient or parent it is almost always by far the most important consideration. In young children or young adults it is often stressed out of all proportion while faulty memory or emotional disturbance, which have such an impact on rehabilitation go relatively unremarked.

$\dagger$ Paper presented at Post-registration Course preceding the 12th National Council Meeting of the South African Society of Physiotherapy, May 1977.

*Physiotherapist, St. Vincent's School for the Deaf, Johannesburg:
Professor Solomon, Professor of Orthopaedics at the Witwatersrand University, at his inaugural lecture suggested that emotional stress or crisis is often the underlying cause of accident or injury; alternatively the patient who sustains injury may subconsciously be resisting recovery because the injury is a convenient hook on which to hang emotional problems.

The impact of severe physical trauma transcends its physical limits and frequently gives rise to an emotional crisis. We know that following serious injury there is a period in which the patient as well as close relatives experience overwhelming fear, grief and loss; a period of mourning follows and finally there is adjustment and rehabilitation. Throughout this period it can be of inestimable value if the physiotherapist has some knowledge and understanding of psychology and counselling. This knowledge used wisely is the basis of a sensitive humanistic approach which can immeasurably increase the effectiveness of mechanistic skills.

The patient's relationship with the physiotherapist is often the first close relationship after the onset of physical disability and as such it is a relationship emotionally charged. It is with the physiotherapist that the patient makes his initial discoveries of what he can or cannot do. With the physiotherapist the patient not only tests his physical prowess but also his self-esteem and this is perhaps the most important part of his adjustment and rehabilitation.

Quoting Dr. Yvonne Blake, a well known Johannesburg psychologist:

"Rehabilitation will depend on:

1. Who the patient is and what he expects, hopes and fears from the situation.

2. Who the therapist is and what motivates her work and relationship with the patient.

3. How they interact and how flexible the physiotherapist can be so that the skills in which she is trained can be used to the best advantage with any given patient."

From the beginning of physiotherapy it is important that patient and physiotherapist understand each other's motives and establish mutually acceptable, realistic goals. If the long-term goals are not immediately acceptable, then at least the short-term goals can be settled. It is also important that all those people associated with the patient communicate well with each other and have the opportunity to do so in order to formulate shared aims for the patient so that they can work as an effective team. This consultation should if possible include the family or influential friends. If this is not done, the relationship with the patient is liable to be frustrating and reflect on the results of treatment.

Ideally a psychologist or psychiatric social worker should be available so that the members of the medical team can seek advice and thus prevent or solve frustrations or seek a direction acceptable to the patient and the members of the medical team, but unfortunately the members of the meal situation frequently does not exist. However no matter how close the communication is with experts in psychology, there will be moments during the close daily contact of the physiotherapist with the patient, when the physiotherapist is forced to depend on what knowledge of psychology and counselling she can muster. In this situation unfortunately, warmth and sympathy and a desire to help are often not enough. 
The physiotherapist is particularly close to the patient because she experiences a physical closeness, a tactile contact with the patient which would not be allowed outside a treatment situation. This situation frequently initiates voluntary communications of a kind that no other member of the medical team experiences. In this situation or sometimes in a cheerful relaxed working situation when the patient does not feel threatened, he may communicate more easily than during an official appointment with the psychologist. Likewise this may happen spontaneously in a moment of frustration while attempting something physically or emotionally difficult. If the confidences are relevant to the patient's treatment and recovery, a way should be found of sharing the information with other members of the medical team. During these valuable moments of communication it is important to listen and draw out the patient rather than tell him what to do. The focus should be kept on the patient. He should be encouraged to give vent to his feelings freely, though good practical suggestions or solutions from the physiotherapist are always helpful and valuable. The army is a place where the stiff upper lip is traditional, but a patient needs a time when encouragement or permission is given to express feelings. Talking things over with a sympathetic listener can help a great deal and by thinking things through logically emotional growth is often achieved. Crisis can be a time of challenge and emotional growth, impossible as it may seem at the time. When a crisis occurs it is very important for the physiotherapist to recognise the crisis and to be available and to put aside other work.

Talking in terms of emotional growth as a consequence of physical injury and disability, I can think of a remarkable example - a man injured while with the South African forces during World War II. My first job as a student was in the military wards at the Johannesburg Hospital. A fellow student worked in the ward with me and for some time she had struggled unsuccessfully to motivate a man with a spinal injury to do breathing exercises and trunk strengthening exercises. $\mathrm{He}$ shouted at anyone who touched him, and it was clear that he could not reconcile himself to living as a paraplegic. The student was becoming desperate, and I looked up one day to see these two confronting each other. She was really telling him what she felt about the impact his behaviour was having on his wife and two little sons. Now 1 feel pale at the thought of the risk she was taking, but at that time there was no expert available to consult before taking such a risk. However it was a case of a man of innate strength and a match of temperament or chemistry and she broke down the barrier and got through to him. He became his old courageous self and finally went back in a wheelchair to training horses. His spiritual strength and stoicism increased steadily and others in the ward were helped by this man's courage and understanding. Nowadays one would go and find expert help before taking this sort of action.

Every physiotherapist experiences match and mismatch of personality at some time, often due to transference of feelings from the past encroaching on the relationship. The film "The Raging Moon" was an excellent picture of a patient suddenly struck down by serious disability, and his slow adjustment and relationships with the staff and other patients. I am told that the book is even better. Mismatch of temperaments is often a hopeless situation and best recognised for what it is. The patient can be quietly and tactfully changed to another physiotherapist. Where there is a very warm relationship, be careful to keep it within limits that will remain constructive for the patient. Withdrawal from a relationship which has meant a great deal to the patient, because it has become too taxing, is difficult to handle.

Rewards of praise and appreciation from the physiotherapist for good co-operation should be immediate in the case of a young child, and even older patients appreciate this; poor work should receive far less obvious attention. The family should be taught this too. Class work in army wards may help a man appreciate that he is not the only one who has suffered shock and loss, There are many practical ways of showing sympathy
as well as knowledge.

A happy flexible working atmosphere that gives cognisance to peoples' emotional needs is well worth striving for, both for the patients and for the members of the medical team.

In conclusion, in vjew of the fact that so many illnesses are regarded as having a psychosomatic origin or in. fluence and that where health is concerned so many factors interact and overlap, physiotherapists should be fully aware that they are frequently involved in a counselling situation and that whenever long-term rehabilitation work is undertaken this is particularly true.

Other paramedical professions have long acknowledged the importance of this counselling relationship by virtue of the fact that in their courses psychology is studied for three years. Therefore it would seem necessary for the physiotherapy profession to press for better theoreti-t cal education and practical involvement in the field of psychology and counselling.

\section{ACKNOWLEDGEMENTS}

Goodman, M., Snr. Physiotherapist, Transvaal Memorial Hospital. Discussion and advice.

Herbert Martin, University of Leicester, Paediatric Assessment Centre, Royal Infirmary.

Lectures and notes on Behaviour Modification and techniques of Counselling.

Irwin, C., Snr. Psychiatrist, Transvaal Memorial Hospital.

Observer status granted at counselling sessions at Transvaal Memorial Hospital, Department of Psychology.

Mathias, A., Chief Physiotherapist, Johannesburg Hospital.

Discussion and advice

Poss, S., Snr. Social Worker, Johannesburg Hospital. Discussion and advice and reading references.

Solomon, L., Prof. of Orthopaedics, University of the Witwatersrand.

Inaugural lecture. The Humanistic Approach as opposed to the Mechanistic Approach to Orthopaedic Surgery.

Zimmler, A., Snr. Psychologist, Crisis Clinic Johannesburg.

Lecture to the S. Tul. branch of the SASP on "Crisis Intervention".

\section{BIBLIOGRAPHY}

1. Blake, Y. (1975), Patient Therapist Relationship. Paper read at the Jubilee Congress, S.A. Society of Physiotherapy, Johannesburg.

2. Bauer, D. (1975), Chartered Society of Physiotherapy Journal.

3. Dyer, L. (1975), Hospital Advisory Service. Paper read at the Jubilee Congress of the S.A. Society of Physiotherapy.

4. Mackeith, R. (1973), The Feelings and Behaviour of Parents of Handicapped Children. Developmental Medieine and Child Neurology, 15, 524-527.

5. McLaren, S. H. (1975), Play for Work. S.A.J. Physiotherapy.

6. Mathias, A. (1976), Counselling in Physiotherapy. S.A. J. Physiotherapy.

Continued on page 13 